\title{
A alteridade em canções de Chico Buarque de Hollanda: uma leitura desconstrucionista
}

\section{The alterity in Chico Buarque de Hollanda's songs: a deconstructionist reading}

J osé Célio Freire*

Universidade Federal do Ceará - UFC, Fortaleza, CE, Brasil

Renata Ramalho de Queiroz**

Universidade Federal do Ceará - UFC, Fortaleza, CE, Brasil

\begin{abstract}
RESUMO
Este estudo pretendeu exercitar as possibilidades de compreensão do texto de algumas canções de Chico Buarque de Hollanda, para além da intencionalidade do autor, visando sua alteridade e a produção de subjetividade que tal leitura encerra, a partir de elementos desconstrutores específicos: acontecimento; ocultamento/desvelamento; multiplicidade; polissemia; inversão; e diferença/alteridade. A investigação mostrou também que o texto buarquiano possui características tais como a atemporalidade e o uso de personagens que representam figuras do desamparo. O ensaio desconstrucionista nos permitiu explorar outras compreensões para o texto original, que já estavam potencialmente existentes. Concluímos que o outro comparece na obra estudada como o outro do texto, como o outro no texto e como um outro texto.
\end{abstract}

Palavras-chave: Alteridade, Subjetividade, Desconstrução, Leitura, Chico Buarque.

\begin{abstract}
This study intended to practice the understanding possibilities of the text of some songs by Chico Buarque de Hollanda, beyond the author intension, objectifying its alterity and the production of subjectivity that this reading provide, from specific deconstruction elements: event; occulting/unveiling; multiplicity; polysemy; inversion, and difference/alterity. The research also showed that the Buarque's text has particulars like the timelessness and the use of characters that represents figures of helplessness. The deconstructionist reading allowed us to explore others understandings to the original text, which were already potentially exist. We conclude that the other appears in the composition studied as the other of the text, as the other in the text and as another text.
\end{abstract}

Keywords: Alterity, Subjectivity, Deconstruction, Reading, Chico Buarque.

Tomar a obra de Chico Buarque de Hollanda ${ }^{1}$ como objeto de investigação teórica não é uma tarefa inédita. Pela via da literatura crítica sobre o autor temos pelo menos treze livros em edição 
nacional. Isso nos indica o alcance que Chico Buarque tem, para além dos registros da Música Popular Brasileira. Muitos trabalhos, acadêmicos ou não, têm se debruçado sobre as inúmeras nuanças dessa vasta obra, seja pelo veio poético (SILVA, 1974), seja pelo comprometimento político (CESAR, 2007; MENESES, 2002), por sua apreensão do feminino (MENESES, 2001; FONTES, 2003) ou mesmo pelo viés semiótico (COSTA, 2004; FERNANDES, 2004; RIBEIRO NETO, 2004 In: FERNANDES, 2004).

O valor do autor no cenário nacional, no que toca principalmente à sua face poética como compositor/letrista, é indiscutível. Todavia, é o texto buarquiano que nos interessa, e nele a dimensão do outro como constitutiva da subjetividade (LÉVINAS, 1978). Tomando esse pressuposto, intentamos buscar na escrita de Chico Buarque elementos polissêmicos, de suplementaridade e de disseminação próprios da différance (DERRIDA, 1991) e que remetem à alteridade radical em sua visada ética (LÉVINAS, 1978; 1980), para além da intencionalidade do autor.

A fim de que a leitura de textos buarquianos (HOLLANDA, 2006) pudesse nos conduzir na direção da alteridade radicalizada, a partir dos rastros deixados pelo autor em sua escrita, utilizamos os recursos da desconstrução (Jacques Derrida), enquanto "método" de descentramento do texto que mobiliza forças que estão sendo agenciadas internamente aos discursos. Tomamos ideias, temas e proposições valorativas, que aparecem na escrita de Buarque, e propusemos 'torções' que fizeram surgir possibilidades outras de sentido - seus diferendos - e, com isso, um outro texto, o nosso, como suplemento ao texto original.

Em nossa pesquisa efetuamos, num primeiro movimento, a (re) leitura dos textos, procurando identificar elementos (rastros) que apontassem na direção de um reconhecimento da alteridade radical o outro enquanto absolutamente outro, diferença irredutível. Num segundo movimento tratamos desses elementos, nos textos, visando fazê-los diferir de uma primeira compreensão, na busca de significações várias (polissemia) e da explicitação de tais possibilidades. Num terceiro movimento, propusemos novas significações para o conteúdo dos textos, reenviando a outras leituras possíveis (disseminação).

Esta investigação pode fornecer novos elementos para uma compreensão dos dispositivos envolvidos na constituição das subjetividades, via literatura, e, num sentido estrito, pela leitura dos textos das letras de canções. Claro está, para nós, que a obra buarquiana no âmbito da Música Popular Brasileira é mais ouvida que lida. A música, nesse caso, só acrescenta à capacidade de entendimento dado o "seu poder de penetração nas massas, através da conjugação poesia-melodia", conforme nos alerta Fontes (2003, p. 6). De acordo com esta autora, a conjugação letra/música confere 
uma maior expansão da poesia do que o texto poético propriamente dito, pois o público de hoje em dia é mais afeito à audição do que à leitura de textos poéticos. Para ela, não há em Chico Buarque a intenção de ser reconhecido como poeta, mas sim como compositor. Contudo, muitos estudiosos da literatura atestaram a qualidade literária das letras das canções de Chico e conferiram a elas o status de textos poéticos. Todavia, sem a música, o texto poético pode ser lido, como faremos agora, em seus dispositivos agenciadores de subjetivação.

\section{Elementos desconstrutores nas canções de Chico Buarque}

Uma leitura descontrucionista em busca da multiplicidade e polissemia de significados é possível de ser realizada na obra buarquiana, dado que suas letras propiciam a disseminação de ideias, isto é, uma abertura para novas formas compreensivas. Possivelmente, a procura de novos significados seja até mesmo congruente com a postura estética (criativa) do compositor, pois, como bem ressalta Conde (2004), o próprio Chico Buarque entenderia as palavras como estando vivas. De fato, em Uma palavra (1989), Chico diz: "Palavra prima [...] que quer dizer tudo/anterior ao entendimento, palavra/palavra viva/palavra com temperatura [...] palavra dócil [...] que se acomoda [...] e que me escreve desatento [...] quase-palavra [...] palavra boa [...] de habitar/fundo/o coração do pensamento, palavra".

Isso tudo implica, para o nosso estudo, na produção de elementos desconstrutores que a obra buarquiana permite. Poderíamos arrolar alguns deles, que iremos tratar agora: acontecimento; ocultamento/desvelamento; multiplicidade; polissemia; inversão; e diferença/alteridade. Utilizaremos algumas canções de Chico Buarque que nos permitem deflagrar esse processo criativo, ou seja, ver para além do que o autor quereria mostrar, o dizer que habita nas entrelinhas do dito (LÉVINAS, 1978).

Tal processo se dá na interpenetração de três movimentos: o que busca a alteridade no texto, incluindo aí a sua forma radicalizada como aparece em Emmanuel Lévinas; o que se depara com os diferendos, ou seja, aqueles elementos polissêmicos já presentes na obra; e ainda um outro, que permite novas significações, resultado daquilo que entendemos por disseminação, esta assumida por nós mesmos, leitores que somos.

\section{Elemento 1: acontecimento - "seria um acontecimento" (Cadê você, 1987)}

Na canção A banda (1966), podemos observar o povo a sair de sua rotina pelo advento da música. Sant'Anna (2004) caracteriza esse movimento como uma abertura dos indivíduos em relação à música, quando todos são solicitados a ver, ouvir e dar passagem à banda, 
participando, assim, da festa da vida. Desta forma, antes da passagem da banda, existia a rotina, o silêncio, o fechamento. Com a passagem da banda, há um evento, a música, e uma abertura para a mensagem que está sendo omitida. Por fim, depois que a banda passa, há um retorno à rotina, ao silêncio e ao fechamento.

A banda provoca, assim, um rompimento, uma ruptura daquela condição considerada como normal, provocando uma polarização na atitude dos indivíduos que presenciam sua passagem: o homem sério para de contar dinheiro; o faroleiro para de contar vantagem; a namorada para de contar as estrelas; a moça triste sorri; a rosa fechada se abre; o velho fraco se esquece do cansaço e a lua escondida aparece. Com a banda, podemos perceber a irrupção do novo, do inusitado, do diferente. Porém, todas as mudanças provocadas pela música da banda são efêmeras, pois depois de sua passagem, cada um voltou para o seu canto e para a sua dor.

Contudo, concebemos uma outra forma de compreender o impacto da passagem da banda que difere dessa visão de que as mudanças provocadas pela banda foram efêmeras e que, depois da sua passagem, tudo voltou a ser como era antes, como se a banda tivesse provocado apenas uma pausa ou uma suspensão. De acordo com a ideia de Sant'Anna (2004) de que a passagem da banda provocou uma abertura, podemos dizer que a banda significou um acontecimento, uma novidade que fez irromper o diferente, o inusitado, o intempestivo. Assim sendo, algo mudou, algo diferiu, algo rompeu e se transformou, ou seja, as coisas já não são mais as mesmas, as pessoas que se deixaram afetar pela passagem da banda, igualmente, mudaram e se transformaram. Se a banda foi realmente um acontecimento, as pessoas já não são mais as mesmas, elas são, agora, diferentes. Nesse sentido, podemos dizer que o acontecimento marcou, deixou um rastro, um sulco, um vestígio.

O acontecimento é, então, aquilo que irrompe, aquilo que não era esperado e que produz uma diferença, um traumatismo segundo Lévinas (1978) - o ser afetado. Nessa linha de pensamento, podemos dizer que essa letra tenha sido para nós um acontecimento que produziu uma diferença, uma diferença de leitura. $O$ ato criador que gerou essa letra criou a possibilidade de outras leituras, de outros atos criadores. Assim, esse texto buarquiano, como outros ao longo deste trabalho, nos instigou a fazer isso, a fazer uma releitura, uma recriação, uma experimentação, ou seja, a canção de Chico Buarque nos jogou no caminho da experiência (LARROSA, 1998).

\section{Elemento 2: ocultamento/ desvelamento - "quarta-feira sempre desce o pano" (Sonho de um carnaval, 1965)}

Nessa letra, assim como em Noite dos Mascarados, a máscara assume o papel de ocultação, escondendo o que não deve ser 
revelado - a identidade. A Persona - máscara no grego - representa tudo aquilo que se mostra e que se desvela, enquanto que a máscara carnavalesca representa o que esconde e que se oculta. Em outras palavras, a máscara procura ocultar a identidade, a "verdade", as características e as "reais" emoções do sujeito. Desta forma, ela acaba possibilitando que o indivíduo assuma uma atitude mais descolada de sua identidade e de seus comportamentos previsíveis, podendo agir de maneiras inusitadas, novas e diferentes.

Isso significa que, para além de sua função de ocultamento, a máscara possibilita a irrupção do diferente - o diferendo -, o estranho que comparece ao encontro com o estrangeiro: o diferente de si se encontra com a diferença do outro. Ou seja, já não há uma identidade a ser preservada. Pelo menos não há a identidade do idêntico a si mesmo - o eu verdadeiro ou autocoincidente.

Por outro lado, podemos considerar que, na medida em que o individuo se descola de suas convenções sociais e de suas características cristalizadas, ele tende a ficar livre de injunções, de qualquer essência que pudesse identificá-lo a priori. Está mais livre para ser e agir no mundo de forma criadora. Assim sendo, podemos compreender a máscara como uma permissão que o sujeito se dá para "se soltar" e "ser o que pode ser", aproveitando o momento como deseja e não como o meio social espere que ele aproveite.

Ao usar uma máscara, a pessoa esconde o seu rosto. Esse rosto, porém, que significa face, possui um sentido diferente do Rosto como proposto por Emmanuel Lévinas. O Rosto levinasiano traz a dimensão do Infinito através do outro, da diferença, sendo aquilo que se manifesta e não o que se mostra. O que se mostra é fisionomia. Nesse sentido, posso dizer que eu escuto o Rosto (ele me fala), que é do outro, e esse Rosto manifesta, para mim, o Infinito. Na verdade, ao ocultar o rosto, a máscara possibilita o desvelamento do Rosto. Em outras palavras, se não estou vendo o rosto, tenho a chance de escutar o Rosto e deparar-me com a infinitude.

Calado (2004) considera que, de acordo com as leis do carnaval, há uma liberação das relações. Ainda que provisória, tal liberação permite que os indivíduos, geralmente separados na vida cotidiana por barreiras sócio-culturais, estabeleçam uma forma de contato mais livre e familiar.

A composição Quando o carnaval chegar (1972) também evidencia esse caráter de transformação, libertação e permissão, pois quando o carnaval chegar, o conformado e resignado eu lírico, que vem se guardando por muito tempo, se permitirá "sambar", "falar", "agarrar", "beijar", "revidar", "cantar" e "gritar". Há, aqui, a ideia de que o carnaval possibilita a mudança e a tomada de atitudes inusitadas, impensáveis e surpreendentes. E aqueles que aguentam passivamente as proibições, as regras e os limites da vida cotidiana podem sair desse marasmo e "explodir" com toda força durante o 
carnaval. Deste modo, podemos observar uma nítida separação entre as atitudes assumidas na vida cotidiana daquelas adotadas no carnaval.

De acordo com Calado (2004), os elementos da canção que constituem a vida cotidiana podem ser considerados dentro do campo semântico da "Repressão", uma vez que justificam as seguintes atitudes: "sempre parado", "não posso falar", "há quanto tempo desejo", "me ofende, humilhando, pisando", "apanhando da vida", "tanta alegria adiada, abafada". Em oposição, temos os elementos que constituem o campo semântico da "Permissão" e que sugerem ação, realização dos desejos e poder, como podemos observar nos verbos "revidar", "cantar" e "gritar". Nas palavras de Calado (2004, p. 283): "Através dessa oposição entre os campos semânticos "Repressão" x "Permissão" cria-se a relação "vida oficial" $x$ "carnaval", "repressão" x "permissão".

Na canção I racema voou (1998), Chico retrata uma mulher brasileira que, sacrificando-se, vai ao encontro do estrangeiro, do novo, da modernidade. Ela não espera mais pela modernidade no Brasil, mas vai até ela, voando para lá. Como bem ressalta Fischer (2004), a revoada de Iracema representa uma das significativas características de nossos tempos: a migração dos habitantes da periferia na direção dos centros.

Retratada em sua individualidade e sem contexto explícito, a Iracema de Chico, mesmo não dominando o inglês, sai do Ceará para tentar ganhar no estrangeiro. Vivendo clandestinamente, "não dá mole pra polícia" e vai levando a vida como pode com o seu trabalho ilegal. Entretanto, mesmo com as dificuldades de uma vida clandestina, Iracema ainda sonha e "Ambiciona estudar/ Canto lírico".

De acordo com Fischer (2004), longe de ser uma personagem autônoma e forte, Iracema é, pelo contrário, anômala, anômica e anódina, ou seja, é uma personagem que pode parecer com qualquer pessoa e com todo mundo.

Além de I racema, outros personagens de Chico Buarque também são sujeitos sem contexto explícito, como Pedro Pedreiro e a morena de Angola. Segundo Fischer (2004, p. 294): "Chico parece preferir os indivíduos flagrados em sua singeleza, em quadros descritivos e narrativos de grande poder de representação de vida e de imensa eficácia estética, quadros que permanecem". Desta maneira, o compositor reserva para si o papel de narrador ou interlocutor, deixando claro que não intenciona fazer análise, mas deseja dar vida ao indivíduo. Mas esse indivíduo é o outro em sua nudez e miséria (LÉVINAS, 1993) que traz a ideia de infinito, para além de sua condição finita.

Voltando ao início desta nossa leitura, a verdade se dá enquanto desvelamento/ocultamento (HEIDEGGER, 1995), e não como correspondência entre representação e coisa ou concordância entre 
conhecimento e objeto. Portanto os fenômenos se dão a conhecer ocultando-se e desvelando-se, ao mesmo tempo. Em Lévinas tal acontecimento é mais que revelação, manifestação do Infinito no finito

\section{Elemento 3: multiplicidade - "De todas as maneiras"(título homônimo, 1980)}

Certas letras de músicas se relacionam com determinada época, podendo ser compreendidas dentro do contexto daquele tempo. Diferentemente, as canções de Chico Buarque são atemporais, uma vez que elas fazem sentido em qualquer época, em qualquer tempo, pois as relações tratadas em suas letras são da ordem existencial e fenomenológica. Por exemplo, Vai passar (1984): "Vai passar... Num tempo ... E um dia, afinal", indica-nos que tudo passa e, no entanto, há uma memória e uma futurição. Assim como a letra de Apesar de você (1970), escrita no contexto da ditadura militar, pode fazer sentido em situações outras que não digam respeito à ditadura, possibilitando, desta maneira, uma multiplicidade de leituras e interpretações. Portanto, não há porque ficarmos presos a uma interpretação política como "canção-vivência" (CONDE, 2004, p.246). Trata-se aqui do tempo múltiplo, do atemporal ou do extemporâneo.

De acordo com Ribeiro Neto (2004), no disco As cidades, de 1998, Chico retrata a multiplicidade do universo urbano em canções que abordam o indivíduo desde sua solidão amorosa até sua inserção ou marginalidade social. As cidades aparecem como lugar de referência e refúgio, de necessidade e exclusão, de acolhimento e exílio. As frases musicais desencontradas incomodam nas primeiras audições, mas passam a surpreender, ao longo do tempo, devido à harmonização delicada e sutil, quando o estranho, ou seja, o diferente, a alteridade, se torna belo.

Da mesma forma que podemos dar múltiplos significados às canções buarquianas, abrindo novas possibilidades para suas letras, Chico Buarque parece ter feito o mesmo com a canção As vitrines (1981), ao criar uma segunda letra, que permanece apenas no encarte do disco Almanaque. A "letra 2" vem disposta nesta segunda capa como avesso da primeira, repetindo o texto original dos versos iniciais e apresentando, em seguida, frases aparentemente sem sentido. Scchin (2004) defende que o final da primeira letra serve como gancho para a entrada da segunda. Ele nos diz:

Ora, isso se viabilizou, e se prenunciou, exatamente no término da versão original: lá estava o sujeito catando a poesia entornada no chão. Literalmente, foi com tais cacos da palavra poética que ele montou o texto 2: o anagrama revela o poema possível a partir do "transbordamento" do primeiro, tão intenso que de seus fragmentos reconstituídos fez-se integralmente um segundo poema ( $p .183$ ). 
Outra possibilidade de ver o múltiplo é como excesso. A mulher de As vitrines (1981), que escapa, que está fora de contato, se apresenta, ainda, como um excesso, um transbordamento. Ela reapresenta, então, o outro que me excede, que me extrapola. Só resta ao eu lírico ir "catando a poesia que [ela] entorna(s) no chão". Nas palavras de Sechhin (2004), "O transbordamento dessa mulher que "gostava de ser' permite a ele [...] apossar-se de sobras ou cacos de poesia, como a metonímia possível do outro em definitivo perdido". Além disso, ela entorna porque é excesso, porque não cabe em si mesma.

A ideia de excesso, de transbordamento, pode ser aproximada da compreensão do outro como o que me ultrapassa ou que não pode ser abarcado, compreendido ou tematizado. É, portanto, da ordem do desejo, mas um desejo ungido pelo excesso (não pela falta), "como um pensamento que pensa mais do que não pensa, ou do que aquilo que pensa" (LÉVINAS, 1988, p.84).

\section{Elemento 4: polissemia - "pra se viver do amor há que esquecer o amor" (Viver do amor, 1977-8)}

De acordo com Perrone, Ginway e Tartari (2004), o repertório musical buarquiano é permeado por uma mistura de efeitos linguísticos e musicais que provocam ironia, intensificam estados anímicos e colaboram para a dramaticidade performática. A estruturação criativa, a variedade de personagens, formas e gêneros, e a plurissignificação composta de notas, ritmos, harmonias e palavras caracterizam a obra de Chico Buarque, que se utiliza de diversas estratégias (narrativas, caricaturas, alegorias, sátiras e intertextualidade) com o objetivo de expor divergências e discrepâncias ou articular emotividades cambiantes. Desta forma, Chico pode ser caracterizado como um compositor de letras delicadas e fortes cuja originalidade enriqueceu o cenário do samba e da canção sentimental. É importante ressaltar, ainda, a carga afetiva e ética de sua obra que representa a consciência social de uma geração. Até porque, para Lévinas, o ético é da ordem do ser afetado, do afeto, portanto. E isso pode ser identificado nas composições buarquianas - a dimensão ética nos chega, geralmente, pela via do afeto, carregada de muita sensibilidade, passividade e vulnerabilidade.

Na canção As vitrines (1981), acompanhamos as tentativas, em vão, do eu lírico advertir a uma mulher sobre os perigos da cidade. Apesar das insistências do eu lírico, procurando impedir que a mulher escape do seu domínio, ela se lança para um território que está além dos domínios daquele que adverte. A mulher se apresenta, aqui, como um objeto incontrolável, como um objeto perdido (SECHHIN, 2004). Nesse sentido, esta canção nos mostra o outro que me escapa, que foge do meu controle. Por mais que o sujeito tente impedir o escape 
dessa mulher, ele não consegue, pois não tem o controle, o poder (ou o saber) sobre o outro. Como bem ressalta Sechhin (2004), "O tempo todo o sujeito vai desejar o unívoco, o situado, ou, no limite, o estático e o aprisionado, enquanto o objeto de seu desejo será cada vez mais deslizante, fugidio, impreciso, múltiplo" (p. 180). O Outro escapa, não se deixa conter, é excesso que transborda, como vimos um pouco atrás.

Voltando à letra de Chico, contudo, o eu lírico acaba por se defrontar justamente com aquilo que ele tentou rejeitar, enxergando as vitrines não por vontade própria, mas por meio de um espelhamento encontrado nos olhos da mulher. Segundo Sechhin (2004):

\begin{abstract}
A atmosfera lúdica e prazerosa que envolve a mulher deixa como resto, ao homem, uma sombra multiplicada. Em vertiginosos deslocamentos propiciados pelo desfile feminino, abolem-se fronteiras entre observadores e observada, entre sujeito que vê e objeto que é visto. Desejando-a unívoca, o homem se depara com o múltiplo [...] (p. 181).
\end{abstract}

Joana Francesa (1973), por sua vez, é uma letra polissêmica por natureza. Misturando a língua francesa à portuguesa constrói sentidos vários para a declaração de amor pelos amantes. Tu mens trop (mentes tanto) pode ser 'tu me entrou'; "geme" confunde-se com j'aime (amo); "acorda, acorda" transforma-se em d'accord, d'accord (de acordo, de acordo); marée, bateau (maré, barco) pode ser ouvido como 'me arrebatou'.

O uso de múltiplos significados para um mesmo termo é evidente na letra de Paroara (1985). A palavra "cara" aparece quatro vezes em diferentes acepções. "queimou nossa cara" (rosto, face); "e não tava cara" (preço elevado); "um cara apareceu" (sujeito, indivíduo); "mas não tinha cara" (não parecia, não tinha aparência).

Um outro exemplo de polissemia vem da canção Pelas tabelas (1984). Fontes (2003) considera inegável o apelo político da canção, mesmo estando ele como pano de fundo. Segundo a autora, "se a temática do texto da canção se funda a partir de um movimento político, ela é política, ainda que para configurar uma alienação individual em relação a um estado de mobilização coletiva" (p. 17). Chico Buarque nega o engajamento político da canção e a descreve como uma música de amor. Entretanto, concordamos com Fontes (2003) quando ela defende que não cabe a Chico direcionar a interpretação do público, pois não se pode interceptar a pluralidade de significado gerada pelo signo linguístico.

\title{
Elemento 5: inversão - "a gente vai contra a corrente" (Roda Viva, 1967)
}

Em Injuriado (1998) podemos perceber uma inversão, ou seja, um discurso às avessas como bem observa Ribeiro Neto (2004) ao 
ressaltar que o eu-lírico "nega gratuitamente para firmar-se como afirmação" ( p. 170), pois ao mesmo tempo que desdenha a amada, ele a deseja "comprar". O injuriado sente-se assim porque não entrou no jogo, ou contrajogo: trata-se de uma antilógica - fazer o bem demais, ser o "bonzinho" - colocando o outro na obrigação de retribuir. Percebemos que há, nessa canção, a ideia de que quem é bom demais acaba incomodando. Essa letra faz parecer que ninguém suporta aquela pessoa que faz tudo e que está sempre à disposição. Popularmente, o sujeito bonzinho demais é, muitas vezes, sentido como uma pessoa que acaba cansando e incomodando, pois, implicitamente, traz no seu ato de bondade uma obrigação de retribuição por parte daquele que recebe.

Desta forma, o sujeito da canção está injuriado porque a amada não entrou no jogo "eu não te dou valor, para você me dar valor", numa lógica de que se você só faz o bem, você cansa o outro e esse outro acaba desprezando você. Nesse sentido, de certa maneira, seria preciso fazer o mal também, para mostrar que o outro não é tudo e para que esse outro não acabe desprezando você.

De acordo com a antilógica da canção, se o sujeito só fizesse o bem, se ele tivesse emprestado dinheiro ou se tivesse feito favores à amada, ele estaria viciando e alimentando o gênio ruim dela, que acabaria o desprezando. Contudo, como o eu lírico fez mal à amada e ela, portanto, nada lhe deve, ele, agora, se pergunta porque ela, ao contrário do esperado, está injuriada e falando mal dele.

Mas em Lévinas (1988), ser pelo outro não implica na recíproca, pois isso é negócio dele (do outro). Isso que a letra diz pode se assemelhar ao signo do amor (Deleuze, 1987) onde a mentira, a ocultação, a dissimulação fazem parte do jogo entre os amantes. Além do que, em Lévinas, amor tem a ver com doação (dação), o que não conseguimos captar na letra.

A canção O malandro (1977-1978), por sua vez, descreve a malandragem em uma ordem gradativa, crescente e hierárquica que vai desde o malandro até os ianques. Segundo Gouveia (2004) "há uma ordem temporal linear representada pelas ações dos diversos malandros" (p. 195-196). Tal linearidade é composta por elementos que não podem sair do lugar, uma vez que o roubo inicial desencadeia todos os outros acontecimentos. Assim, a canção possui o primeiro movimento: o malandro - o garçom - o português - o distribuidor - o usineiro - o Banco do Brasil - os ianques. Em contrapartida, no momento em que os ianques não aceitam a lesão, atinge-se o limite supremo do encadeamento da ação e a canção assume um segundo movimento que retrata o retorno da malandragem: os ianques - o Banco do Brasil - o usineiro - o distribuidor - o português - o garçom - o malandro. Há, assim, uma nova cadeia de ações que se apresenta no sentido oposto, mas que possui uma estrutura idêntica ao movimento anterior, uma vez que 
não desfaz a ordem estabelecida primeiramente. Da mesma forma que o limite superior dessa ordem é representado pelos ianques, o limite inferior diz respeito ao malandro mais pobre. Mas ninguém quer ser lesado - enganado ou bobo. Nisso pode aparecer a dimensão da diferença, pois cada um, a sua maneira, experimenta a possibilidade da perda, ou do ludíbrio.

De acordo com Gouveia (2004) uma questão relevante que permeia essa canção é a autoconsciência do malandro, uma vez que ele tem clareza sobre o alcance internacional da malandragem, critica a impunidade em cadeia e sabe que somente ele será punido. Aqui, é retratada uma consciência plena da malandragem institucionalizada e sem fronteiras que engloba tanto malandros oficiais, quanto malandros menores.

Um outro tipo de estranhamento nos causa a escrita buarquiana, ao apresentar provérbios populares ditos no sentido contrário. Trata-se da canção Bom conselho (1972), em que tais "conselhos" surgem de onde ninguém imagina, irrompem com um significado que traz uma diferença. Como bem ressalta Calado (2004, p. 278), "A inversão semântica de provérbios oferece um aspecto cômico à composição, na medida em que do habitual e esperado surge o inusitado, o efeito surpresa". Tal inversão semântica evidencia o aspecto do inverso, do espelho, do duplo, do não ser no ser, do outro no mesmo presente na canção: "Inútil dormir a dor não passa" [durma que a dor passa]; "Espere sentado ou você se cansa"[quem espera sentado não cansa]; "quem espera nunca alcança"[quem espera sempre alcança]; "brinque com meu fogo, venha se queimar"[com fogo não se brinca]; "Faça como eu digo, faça como eu faço"[faça o que eu digo mas não faça o que eu faço]; "Aja duas vezes antes de pensar"[pense duas vezes antes de agir]; "Corro atrás do tempo"[do tempo não se foge]; "Devagar é que não se vai longe"[devagar se vai ao longe]; "Eu semeio o vento"[quem semeia vento colhe tempestade]; "Vou pra rua e bebo a tempestade"[não faça tempestade num copo d'água].

Desta forma, Bom conselho reforça uma ideia de transgressão e desordem num contexto onde imperava a repressão e a ditadura. A linguagem proverbial conservadora, que incentiva a passividade e a resignação, transforma-se numa voz transgressora desse universo conformista, que faz um convite à ação e prega a desobediência à ordem estabelecida. Contudo, essa ideia pode ser estendida para qualquer época, e não só para aquele período de exceção.

Com efeito, Conde (2004) considera que essa canção realiza uma espécie de "violação proverbial", pois enuncia, justamente, o contrário daquilo que os provérbios populares pregam. Contudo, o autor considera que essa própria violação é de domínio público, uma vez que, detentora de uma certa verdade, possui uma enunciação severa que preserva os traços da sabedoria popular. Diante dessa interpretação, podemos observar que os "bons conselhos" do eu lírico 
podem ser considerados tão sábios quanto os seus contrários pregados pelos provérbios populares. De uma forma ou de outra, há sabedoria e verdade, depende somente do contexto e situação em que é dito.

Em Madalena foi pro mar (1965) a inversão comparece na figura de Madalena (prostituta/santa) que sai para o mar e deixa o seu homem e os filhos em terra. Trata-se de uma mulher pe(s)cadora, mas que merece o perdão - dimensão ética por excelência. Tanto para quem pede, quanto para quem perdoa. Em ambos os casos há que se ter 0 outro em vista.

Já em Folhetim (1977-1978) a inversão se dá quando a mulher do tipo que 'só diz sim', ao final diz ao homem que ele é 'página virada'. Hospitalidade e hostilidade se aproximam como em seus próprios antepositivos hospit (aquele que recebe) e host (estrangeiro). Em inglês, contudo, host é anfitrião. De fato, a hospitalidade é uma dimensão ética também: acolher o outro na sua diferença, ele que chega sem aviso e ao qual devo fazer as honras da casa.

Uma canção desnaturada (1979) produz a inversão pela via da reversão - o desejo dos pais de que a filha já mulher retorne ao útero da mãe. Ora, eis o inverso da paternidade: o pai torna-se cada vez mais desnecessário ao filho. O filho dista para o futuro, não há como trazê-lo de volta ao regaço.

\section{Elemento 6: diferença/alteridade - “Um dia ele chegou tão diferente do seu jeito de sempre chegar (Valsinha,1970)}

Diferir é adiar, mas também, ser diferente; prolongar, mas também divergir. Há uma dimensão de temporalidade na procrastinação, mas trata-se já de um tempo sem tempo, do contratempo ou do extemporâneo. De um lado, o tempo que cria, que possibilita o ser para além da morte. De outro, a alteridade que inventa o tempo, ser para um outro.

Na canção Tempo e artista (1993), podemos perceber a dimensão de um tempo que modela, de um tempo que age pelo artista e no artista. O tempo é, na verdade, "a grande estrela", uma vez que ele obra a sua arte, modela o artista, põe-lhe rugas, arrebata-lhe a garganta, canta, dança e é autor do drama. Desta forma, assim como nos mostra Meneses (2004), o tempo, dotado de uma potência criadora, é o artista: ele é pintor, escultor, cantor, bailarino, dramaturgo e músico. O artista, por sua vez, possui um momento de ação e um momento de se deixar agir pelo tempo, quando se apresenta como tela, deixa-se modelar, empresta-lhe a garganta e cede-lhe o dorso. Nesse sentido, o artista se coloca como suporte para a ação de um Outro, sendo, assim, objeto e porta-voz do tempo. Tal canção também nos traz a finitude humana ao abordar o tempo como agente de envelhecimento que deixa suas marcas através de rugas, tremor, exaustão e velhice. O passar do tempo representa, 
então, perda e degradação. Lévinas admoesta-nos, também: "Pele às rugas" (1978, p. 141). Por outro lado, a canção também engloba o princípio criador, ao levar em conta a permanência que a arte propicia, quando, na última estrofe, o tempo alcança a glória e o artista, o infinito. Para Emmanuel Lévinas significa o "ser-para-alémda-minha-morte", da obra que posterga o artista. Assim, "Tempo e artista" apresenta um paradoxo entre finitude e infinitude, articulando dialeticamente duas concepções de tempo: a linear e a cíclica.

Tudo isso nos remete a uma discussão mais profunda sobre a temporalidade. Podemos, por exemplo, sair do tempo linear e cronológico até chegarmos a um tempo vivido, atemporal e contratemporal. O tempo, para Lévinas, é o tempo de Moisés, que continua sempre em frente em busca da terra prometida. E não o de Odisseu (Ulisses) que retorna a sua Ítaca. Em outras palavras, segundo o pensamento levinasiano, o tempo significa uma abertura para o futuro e para o novo. Com esse tempo dirigido para o futuro há uma abertura para o outro. Desta forma, o tempo, para o Mim, é - Outro, pois é o outro que demarca meu tempo, ou seja, eu me temporalizo em relação ao outro. Embora sejamos finitos, nós conseguimos ter a ideia de infinito devido ao outro, pois quem nos traz a ideia de infinito é o outro. Da mesma maneira, o princípio criador engloba a dimensão do infinito, pois, uma vez que nos propicia uma abertura para o futuro, o princípio criador nos permite ultrapassar o tempo cronológico para o tempo vivido, que é fenomenológico. Assim, podemos nos transportar para o passado e para o futuro, para o tempo vivido e um tempo não vivido, por viver - devir. O ato criador é para o futuro, é para o outro, é postergação, posterioridade, posteridade. A palavra é adiamento, procrastinação, futurição. A letra da canção impele ao posterior - para um depois, para um ainda não dito, mas por dizer. Por último, o alcance da obra de arte está para além da morte do criador. A obra de arte fica, portanto, para a posteridade.

De acordo com Costa (2004), “[...] o tempo é considerado agente de deslocamento cujos efeitos são matéria de trabalho literomusical de Chico Buarque" (p. 347). O autor considera que a obra de Chico Buarque é marcada por uma condição paracrônica. A paracronia revela uma existência que problematiza a temporalidade, ou seja, o sujeito é capaz de colocar-se além, paralelamente ou aquém de uma obra situada em um dado momento ou mesmo acima de qualquer pertinência temporal. A "embreagem paracrônica" pode ser observada em O velho Francisco (1987), em Homenagem ao malandro (1977-1978) e em Tempo e Artista (1993).

Dessa maneira, o tempo cronológico é uma medida para organizar o tempo, mas não faz sentido do ponto de vista fenomenológico e vivido, dado que o tempo é relativo para cada indivíduo, isto é, o tempo de uma pessoa é diferente do tempo de outra pessoa. 
Temporalidade e alteridade, elementos que se misturam numa constatação de que o meu tempo é do outro, de que o outro me coloca na dimensão temporal.

Na canção As vitrines (1981), o sujeito dirige-se a uma mulher que se encontra vedada ao contato. De acordo com a leitura de Lévinas, por Derrida (1991), só é possível o sujeito se encontrar com vestígios da passagem do outro, mas não com o outro. Isso acontece porque o tempo do outro é um tempo diferente, o outro é o inapropriável, o que não pode ser apropriado, não pode ser minha propriedade, isto é, o sujeito chega sempre em atraso para o contato com o outro.

A obra buarquiana também se caracteriza por retratar personagens excluídos pela sociedade ou silenciados pelo cotidiano. Na canção Juca (1965), podemos observar a abordagem dessa temática quando Juca, por ser sambista, é considerado como um marginal pelo delegado. Segundo Sant'Anna (2004), a canção estabelece dois espaços incompatíveis: o sambista que simboliza a música e a desordem, e o delegado que representa o silêncio e a ordem. Juca estava fazendo uma serenata para sua amada Maria e, "atuado em flagrante", foi preso "como meliante", como perturbador da ordem. Porém, "em legítima defesa", Juca afirma que "o delegado é bamba na delegacia/ mas nunca fez samba/ nunca viu Maria". Aqui, podemos perceber uma diferença, na medida em que o delegado não consegue compreender o que motiva e o que inspira Juca. Em outras palavras, o delegado entende e domina aquilo que é do seu contexto laboral, mas não compreende o outro e o mundo do outro. Nesse sentido, não há a possibilidade dele se colocar no lugar de Juca, ou seja, no lugar da alteridade. O que há é a tentativa de reduzir o outro ao mesmo, o estranho ao familiar, a diferença à identidade.

O sambista é também considerado como "fora da ordem" em outras canções de Chico Buarque, como em Meu refrão (1965), Partido alto (1972) e Mambembe (1972). De acordo com Sant'Anna (2004), ao aceitar sua condição marginalizada, "o excluído passa a excluir-se voluntariamente para melhor assinalar sua exclusão" (p.166). Assim, os excluídos afirmam-se enquanto classe, assegurando seu papel e sua condição social. Esse sujeito fora do contexto comparece em outras letras de Chico como Morena de Angola (1980) e Iracema voou (1998). A Morena de Angola "sai chocalhando pro trabalho", "batucando na panela", "afoita pra dançar na chama da batalha", "faz requebrar a sentinela", "fazendo buchincho com seus penduricalhos", e "tá no remelexo". Ou seja, a ideia central é a perturbação da ordem, a bagunça. Isso que desfaz o previsível, os costumes, os acordos, é da ordem da diferença, da alteridade, da estranheza. Nos casos acima citados teremos personagens que nos colocam diante do disruptivo, da diferença radical. São figuras do desamparo como a viúva, o órfão, o miserável e o estrangeiro de Lévinas (1993), que em sua diferença nos trazem a exigência ética e a dimensão do Infinito. 
Na canção O malandro (1977/1978) podemos observar uma malandragem que implica o outro, que envolve a questão da alteridade. Nas palavras de Gouveia (2004):

\begin{abstract}
A malandragem está generalizada, tem uma maleabilidade que transita nos espaços da ordem e da desordem, e tornase cada vez mais ambígua e de difícil distinção. De fato, não há diferença essencial entre os agentes, mas apenas de grau, uma vez que a astúcia metódica e preconcebida é o elemento unificador de todos (p. 196).
\end{abstract}

Como foi comentando anteriormente, as canções de Chico Buarque costumam possuir um caráter atemporal, uma vez que fazem sentido em muitas épocas e contextos. Desta forma, podemos também constatar a atualidade do tema da malandragem na realidade brasileira, especialmente no que diz respeito à esfera política. Historicamente, sempre fomos governados por malandros que buscavam uma maneira ou outra de se beneficiar do dinheiro público, como podemos observar nos escândalos sistemáticos que os media noticiam e que nos fazem imaginar aqueles que não são tornados públicos.

A composição tríptica O que será (1976) - Abertura, À flor da pele e À flor da terra -, caracteriza-se por um instigante jogo de adivinhação sem solução expressa, deixando, assim, a marca de uma resolução invisível. Tal jogo configura-se através de alusões, negações, afirmações, qualificações e modificações que dão formas e contornos a um tom erótico e sociopolítico. De acordo com Perrone, Ginway e Tartari (2004, p. 217), "A letra sugere algum ente ubíquo, parte da experiência humana, mas sempre elusivo, inefável, indefinível". Trata-se do que foge ao limite, às regras, à Lei, à ordem, portanto o ilimitado, o inovador, o incansável, o transgressor, o indecente, o irreparável. Logo, da alteridade.

Podemos dizer, por isso, que a alteridade está representada na obra buarquiana pelas vozes do malandro, da mulher, do marginal, da prostituta, do pederasta, do pivete, do mendigo e de outros personagens que retratam as minorias marginalizadas, denominadas por Silva (2004) de Coro de Vozes Interditadas.

Na canção As vitrines (1981), apesar de fugir das manifestações da luz, o eu lírico acaba se deparando com o reflexo da luz no corpo da mulher, ou seja, a luz chega até ele via mulher, que ocupa uma função de espelho. Numa relação de alteridade, a mulher representa o outro que mostra para o sujeito uma realidade que ele não queria ver. Haddock-Lobo (2004) nos lembra que Lévinas já havia tratado da alteridade feminina e, mais ainda, que superara esta visão da alteridade por excelência da mulher frente ao homem, para impedir que uma pretensa completude retornasse o outro ao mesmo. No Lévinas de Totalidade e Infinito (1980), a Mulher é o Outro “cuja 
presença é discretamente uma ausência e a partir da qual se realiza o acolhimento hospitaleiro por excelência que descreve o campo da intimidade" (p. 138). Mas no estudo Filosofia, justiça e amor (1982), da coleção de ensaios Entre nós (1997), Lévinas declara: "Outrora, eu pensava que a alteridade começa no feminino. É, efetivamente, uma alteridade muito estranha: a mulher não é o contraditório nem o contrário do homem, nem como as outras diferenças" (p. 155). Derrida (1997) salienta que "é a partir da feminilidade que ele [Lévinas] define o acolhimento por excelência", mas "o acolhimento, origem an-árquica da ética pertence à 'dimensão de feminilidade' e não à presença empírica de um ser humano do 'sexo feminino'” ( $p$. 60).

De acordo com Fontes (2003), na obra de Chico Buarque, a transgressão está intimamente ligada à atitude de valorização da figura da mulher por parte do poeta. Ela ressalta que Chico Buarque tem consciência da condição da mulher na sociedade, da opressão advinda de situações econômicas e culturais que se refletem nas relações amorosas. Por outro lado, Chico também é consciente do encanto, fascínio e atração feminina que resultam em prazeres físicos e espirituais na relação homem-mulher. Assim, podemos observar na obra buarquiana a incidência de múltiplos aspectos do feminino tanto nas canções em que a mulher é a emissora, quanto naquelas em que ela é destinatária ou referente do texto poético. Nesse sentido, Fontes (2003) ressalta que "Da submissão à transgressão, a mulher terá sempre um papel de supremacia, onde se configura a atitude de veneração por parte do poeta ao Grande Feminino" (p. 10). Voltamos à questão da alteridade e da diferença.

Na canção Noite dos Mascarados (1966), podemos observar o diálogo de dois mascarados em meio a uma atmosfera de festa, de fantasia e de brincadeira. Durante o diálogo, os mascarados vão se descrevendo e vão se descobrindo opostos um do outro. Um abismo cada vez mais profundo vai se evidenciando na medida em que aparecem as diferenças de idade, situação financeira e personalidade.

Primeiramente, logo no início da letra, há uma vontade de saber quem esse outro é, provavelmente para ver se combinam enquanto casal, enquanto namorados: "Hoje os dois mascarados/ Procuram os seus namorados/ Perguntando assim:/ Quem é você, diga logo/ Que eu quero saber o seu jogo".

Em seguida, os dois personagens falam sobre si e acabam por descobrir suas diferenças, seus opostos. Porém, no transcorrer da canção, isso tudo parece não mais importar. As polaridades são, finalmente, desconsideradas e deixadas de lado, pois "é carnaval", tempo em que tudo é permitido de acordo com o pensamento popular. A partir daí, não há mais a vontade de saber quem o outro é: "Não me diga mais quem é você". A identidade perde o seu valor e sua importância. Trata-se, agora, de aproveitar o momento, de 
aproveitar a liberação do carnaval, antes que tudo volte a ser o que era: "Amanhã, tudo volta ao normal/ Deixe a festa acabar/ Deixe o barco correr".

Nesse sentindo, é como se a canção nos revelasse as seguintes proposições: não interessam as convenções, as opiniões, os preconceitos; um não tem vontade de saber quem é o outro do ponto de vista socioeconômico, por exemplo; o que importa é que o outro está se mostrando como a diferença, como algo que toca e que afeta; então, de fato, um está se abrindo para o outro, está se abrindo para a diferença, pois está deixando de lado as convenções sociais.

No contexto da fantasia carnavalesca, há, inclusive, a possibilidade de um se amoldar ao outro. A flexibilidade e a transformação são, desta forma, maiores do que as reais diferenças e polaridades: "Que hoje eu sou/ Da maneira que você me quer". Sai-se, assim, da cristalização da identidade, da definição de quem se é. A pessoa que se esconde por detrás da máscara se permite ser diferente, se permite ter outros tipos de vivência e de comportamento. A oportunidade de colocar em suspenso as características identificatórias cria uma relação mais entregue e mais cheia de possibilidades: "Deixa o barco correr... Seja o que Deus quiser". Isso diz respeito, também, a se permitir ser vários eus, ou ser os vários outros.

O tema da diferença é evidente em Geni e o zepelim (1977-1978), sendo tratado pela óptica da discriminação, do preconceito, da hipocrisia e da injustiça. A mulher/travesti que aceita, após a insistência de todos, deitar com o inimigo conquistador para salvar a cidade é depois reconduzida à condição mais abjeta.

Já em Ela é dançarina (eu quero dormir e ela precisa dançar) (1981) o reconhecimento da alteridade chega às raias da impossível convivência. O funcionário, quando pega o ponto, abre o armário, cai morto, não recebe o salário, a dançarina termina o show, salta purpurina, empina e recebe propina.

A obra buarquiana é o "resultado de uma subjetividade construída e marcada irredutivelmente pelas alteridades que, no contexto sóciohistórico de sua produção artística, foram reciprocamente construídas e marcadas por sua obra" (COSTA, 2004, p. 325). O outro, os outros eus, o outro do outro, todas essas formações aparecem nos textos buarquianos, de forma a valorizar a estranheza e a estraneidade, em nós ou sobre nós.

Costa (2004) classifica como paratópica a condição social do escritor. Com isso, ele afirma que o escritor não define um lugar estável no âmbito da sociedade, estando impossibilitado de designar um espaço definido para a sua atividade. Paratopia diz respeito, então, a essa impossibilidade de se estabilizar, a essa localidade paradoxal entre o lugar e o não-lugar. Tal instabilidade radical de, ao mesmo tempo, ser e não ser, faria com que os escritores se solidarizassem com as 
pessoas que, na sociedade, se encontram em semelhante situação. Nesse sentido, a situação paratópica do escritor permite uma identificação com os sujeitos que parecem estar fora das linhas de divisão social (COSTA, 2004).

Desta forma, a bailarina, o palhaço, os homossexuais, os retirantes, as mulheres, dentre outros, assim como os sujeitos individuais (Calabar, Geni, Carolina, Iracema, etc.) fazem parte do universo de personagens paratópicos buarquianos. Tais sujeitos apresentam "uma relação problemática com a sociedade, da qual eles não são meramente excluídos mas interagem simbioticamente com os incluídos, que, por sua vez, nutrem por eles fascínio e temor" (COSTA, 2004, p. 344).

Como exemplo disto, temos o malandro, a mais conhecida categoria paratópica do compositor. O malandro não é propriamente excluído, ele mesmo é quem recusa a inclusão ao não aceitar a ética do trabalho. Na realidade, a malandragem nega a moral do trabalho e da conduta exemplar. Vestindo-se elegantemente e cultivando uma sofisticação burguesa sem corresponder, entretanto, a essa estrutura econômica, o malandro foge da posição de trabalhador e entrega-se à orgia, ao prazer da dança, da bebida e do sexo (COSTA, 2004).

\section{Concluindo}

Apesar de termos feito em nossa análise uma separação dos elementos desconstrutores, é importante o leitor observar que, muitas vezes, estes elementos se fundem, se imiscuem uns nos outros. $^{2}$ Isso nos parece inevitável, o que não implica na incompreensibilidade do texto. De qualquer maneira, quisemos aqui dar vazão ao diferente que as letras de Chico Buarque embutem, a condição de alteridade radicalizada, que obriga à disposição ética do acolhimento e que se dispõe na condição absoluta de vulnerabilidade ao outro.

Seus textos falam-nos da alteridade e produzem alteridades em nós. Somos afetados por expressões como "E cada qual no seu canto, em cada canto uma dor"; "Joga pedra na Geni, ela é feita pra apanhar, ela é boa de cuspir"; "com o seu único e velho vestido, cada dia mais curto"; "te perdôo por te trair"; "foi chegando sorrateiro e antes que eu dissesse não se espalhou feito um posseiro dentro do meu coração"; "apesar de você, amanhã há de ser outro dia"; "me sinto pisando um chão de esmeraldas quando levo meu coração à Mangueira"; "Com açúcar, com afeto fiz seu doce predileto pra você parar em casa"; "morreu na contramão atrapalhando o tráfego"; "todo dia ela faz tudo sempre igual"; "deixa a menina contente, deixa a menina sambar em paz"; "essa moça tá diferente"; "esta terra ainda vai cumprir deu ideal, ainda vai tornar-se um imenso Portugal"; "agora eu era herói e o meu cavalo só falava inglês"; "mirem-se no exemplo daquelas mulheres de Atenas"; "quem te viu, quem te vê"; 
"tem dias que a gente se sente como quem partiu ou morreu"; "trocando em miúdos, pode guardar a sobra de tudo que chamam lar"; etc.

Os textos buarquianos, além de dar voz a sujeitos até anônimos, produzem subjetividades em nós seus leitores (ouvintes). Eles nos tocam pela alteridade (diferenças, estranhezas, avessos) e nos marcam profundamente. Isso reverbera nos encontros/desencontros com outros sujeitos. Mais que pensar, nos faz responder ao outro e responsabilizarmo-nos por ele.

\section{Referências Bibliográficas}

CALADO, L. E. de F. Carnavalização no cancioneiro de Chico Buarque. In: FERNANDES, R. de (Org.). Chico Buarque do Brasil: textos sobre as canções, o teatro e a ficção de um artista brasileiro. Rio de J aneiro: Garamond: Fundação Biblioteca Nacional, 2004, p. 273-284. CESAR, L. V. Poesia e Política nas Canções de Bob Dylan e Chico Buarque. São Paulo: NOVATEC, 2007.

CONDE, G. Do riso cancionista em Chico Buarque. In: FERNANDES, R. de (Org.). Chico Buarque do Brasil: textos sobre as canções, o teatro e a ficção de um artista brasileiro. Rio de Janeiro: Garamond: Fundação Biblioteca Nacional, 2004, p. 243-250.

COSTA, N. B. da. Um artista brasileiro: paratopias buarquianas. In: FERNANDES, R. de (Org.). Chico Buarque do Brasil: textos sobre as canções, o teatro e a ficção de um artista brasileiro. Rio de J aneiro: Garamond: Fundação Biblioteca Nacional, 2004, p. 325-350.

DELEUZE, G. Proust e os signos. Rio de Janeiro: ForenseUniversitária, 1987.

DERRIDA, J. Margens da filosofia. Campinas, São Paulo: Papirus, 1991.

$\overline{1} 9 \overline{9} 5$.

Adeus a Emmanuel Lévinas. São Paulo: Perspectiva,

FERNANDES, R. de. Conformadas e recolhidas: análise de "Mulheres de Atenas". In: FERNANDES, R. de (Org.). Chico Buarque do Brasil: textos sobre as canções, o teatro e a ficção de um artista brasileiro. Rio de Janeiro: Garamond: Fundação Biblioteca Nacional, 2004, p. 371-386.

FISCHER, L. A. Iracema de Chico. In: FERNANDES, R. de (Org.). Chico Buarque do Brasil: textos sobre as canções, o teatro e a ficção de um artista brasileiro. Rio de Janeiro: Garamond: Fundação Biblioteca Nacional, 2004, p. 285-296.

FONTES, M. H. S. Sem fantasia. Masculino-feminino em Chico Buarque. Rio de Janeiro: Graphia, 2003.

GOUVEIA, A. A malandragem estrutural. In: FERNANDES, R. de (Org.). Chico Buarque do Brasil: textos sobre as canções, o teatro e a ficção de um artista brasileiro. Rio de Janeiro: Garamond: Fundação Biblioteca Nacional, 2004, p. 187-204. 
HADDOCK-LOBO, R. As muitas faces do Outro em Lévinas. In: DUQUE-ESTRADA, P. C. Desconstrução e ética. Ecos de Jacques Derrida. Rio de Janeiro: PUC-Rio; São Paulo: Loyola, 2004, p. 165192.

HEIDEGGER, M. Ser e tempo. Parte I. Petrópolis: Vozes, 1995.

HOLLANDA, C. B. de. Tantas palavras. São Paulo: Companhia das Letras, 2006.

LARROSA, J. La experiencia de La lectura. Barcelona: Laertes, 1998.

LÉVINAS, E. Autrement qu'être ou au-delà de l'essence. Paris: Kluwer Academic, 1978.

Totalidade e infinito. Lisboa: Edições 70, 1980.

Ética e I nfinito. Lisboa: Edições 70, 1988.

Humanismo do outro homem. Petrópolis: Vozes, 1993.

MENESES, A. B. de. Figuras do feminino. São Paulo: Ateliê Editorial, 2001.

Desenho Mágico: poesia e política em Chico Buarque. São Paulo: Ateliê Editorial, 2002.

Tempo: tempos. In: FERNANDES, R. de (Org.). Chico Buarque do Brasil: textos sobre as canções, o teatro e a ficção de um artista brasileiro. Rio de Janeiro: Garamond: Fundação Biblioteca Nacional, 2004, p. 147-159.

PERRONE, C. A.; GINWAY, M. E.; TARTARI, A. Chico sob a ótica internacional. In: FERNANDES, R. de (Org.). Chico Buarque do Brasil: textos sobre as canções, o teatro e a ficção de um artista brasileiro. Rio de Janeiro: Garamond: Fundação Biblioteca Nacional, 2004, p. 211-227.

RiBeI RO NeTO, A. As cidades. In: FERnANDES, R. de (Org.). Chico Buarque do Brasil: textos sobre as canções, o teatro e a ficção de um artista brasileiro. Rio de Janeiro: Garamond: Fundação Biblioteca Nacional, 2004, p. 167-171.

SANT'ANNA, A. R. de. Chico Buarque: a música contra o silêncio. In: FERNANDES, R. de (Org.). Chico Buarque do Brasil: textos sobre as canções, o teatro e a ficção de um artista brasileiro. Rio de J aneiro: Garamond: Fundação Biblioteca Nacional, 2004, p. 161-166. SECHHIN, A. C. "As vitrines": a poesia no chão. In: FERNANDES, R. de (Org.). Chico Buarque do Brasil: textos sobre as canções, o teatro e a ficção de um artista brasileiro. Rio de Janeiro: Garamond: Fundação Biblioteca Nacional, 2004, p. 179-183.

SILVA, A. V. da. A poética de Chico Buarque. Rio de Janeiro: Sophos, 1974.

. O protesto na canção de Chico Buarque. In: FERNANDES, R. de (Org.). Chico Buarque do Brasil: textos sobre as canções, o teatro e a ficção de um artista brasileiro. Rio de Janeiro: Garamond: Fundação Biblioteca Nacional, 2004, p. 173-178. 


\section{Endereço para correspondência}

José Célio Freire

Universidade Federal do Ceará, Programa de Pós-Graduação em Psicologia, Av. da Universidade 2762, Benfica, CEP 60.020-180, Fortaleza - CE, Brasil

Endereço eletrônico: jcfreire@ufc.br

Renata Ramalho de Queiroz

Universidade Federal do Ceará, Departamento de Psicologia, Laboratório de Psicologia em Subjetividade e Sociedade, Av. da Universidade 2762, Benfica, CEP 60.020-180, Fortaleza - CE, Brasil

Endereço eletrônico: renatarq@hotmail.com

Recebido em: 20/01/2010

Reformulado em: 06/05/2010

Aceito para publicação em: 21/05/2010

Acompanhamento do processo editorial: Deise Mancebo

\section{Notas}

*Doutor em Psicologia; Professor Associado do Departamento de Psicologia da UFPA.

**Psicóloga pela Faculdade de Psicologia da Universidade Federal do Ceará - UFC; à época da pesquisa, aluna da graduação em Psicologia da UFC e bolsista PIBICCNPq.

${ }^{1}$ Usamos o nome completo Chico Buarque de Hollanda ou formas abreviadas como Chico, Buarque ou Chico Buarque, dado o tratamento já consagrado nos textos e nos media em geral.

${ }^{2}$ Aviso ao leitor: pensar e analisar letras musicais é uma experiência distinta de ouvir as músicas de Chico Buarque ou de analisar os efeitos de sentido dessa audição. Recomendamos as três experiências, embora tenhamos nos detido apenas na primeira. 